\title{
Research on the Data Analysis and Application on the Safety Production of Port Enterprises Based on the AHP-Fuzzy Comprehensive Evaluation Method
}

\author{
Meng Guodong ${ }^{1, \mathrm{a}}$, Wang Yukun²,b ${ }^{2}, \mathrm{Hu}$ Yanhua $^{3, \mathrm{c}}$, Zhao Hong*4,d \\ ${ }^{1}$ Tianjin Dong Fang Tai Rui Technology Co. Ltd, Tianjin, China \\ ${ }^{2}$ Tianjin Dong Fang Tai Rui Technology Co. Ltd, Tianjin, China \\ ${ }^{3}$ Tianjin Research Institute for Water Transport Engineering Ministry of Transport Tianjin, China \\ ${ }^{4}$ Tianjin Dong Fang Tai Rui Technology Co. Ltd, Tianjin, China
}

\begin{abstract}
The production process of port enterprises is complex, and the operation contents are diversified and dynamic. Thus, the factors affecting the safety production risk are numerous and complex. To better grasp the risk state of the safety production of the port enterprises, based on the requirements of relevant laws and regulations and the actual situation of safe production of port enterprises, in this study, the diversified safety production data of port enterprises was collected and analyzed, the three-level index system of safety production data for port enterprises was constructed, the evaluation model of safe production state for port enterprises based on AHP-fuzzy comprehensive evaluation was established, and the practical application was carried out in a large port enterprise. The evaluation results were highly consistent with the actual situation of safe production of port enterprises. This evaluation method can be used to make full use of the existing data sources of safety production of port enterprises to discover the prominent risks affecting safety production and control them, and effectively improve the level of safety production of port enterprises.
\end{abstract}

\section{Introduction}

Ports are the key link of China's waterway transportation, and its safe development is of great significance to regional stability \& prosperity and sustained economic growth $^{[1]}$. The diversified production and operation modes of port enterprises determine the complexity of safety risks. The safety risks are the result of the joint action of people, machinery, materials, environment, laws and other factors. Any abnormal link or element can easily lead to the occurrence of safety production accidents. In view of the numerous restrictive factors affecting the safe development of port enterprises and the status quo that the overall situation of port enterprises is still grim ${ }^{[2]}$, to realize the modernization of the governance system and fine safety management of port enterprises, the only way is to scientifically master the safety production state of port enterprises and thoroughly explore and control the factors affecting safety risks.

At present, the methods to assess the safety state of port enterprises mostly adopted are qualitative or semiqualitative assessment ones, such as conventional safety state assessment and standardized safety production assessment ${ }^{[3-4]}$. Quantitative evaluation methods are mainly aimed at port facilities, working environment, loading and unloading operations or a specific type of accident ${ }^{[5-7]}$. During the production and business operation of port enterprises, safety production data generated from

aiktguodong@163.com, bwangyukun@tk-aq.com

chuyanhua@tk-aq.com,*dzhlucky0311@126.com the operation activities and management reflects the production and operation process of the enterprises. These data are the internal performance of management behavior and production state, and also the important basis for port enterprises to evaluate the work effect of safety production, to grasp the safety production dynamics and to make safety production decisions accordingly ${ }^{[8]}$. In this study, a mathematical model is used to construct a method to assess the safety state of port enterprises based on safety production data, which is helpful to objectively evaluate the safety risk state of port enterprises and find out the weak links of safety management. By utilizing big data, comprehensive analysis and evaluation on the safety production state of port enterprises can make the safety assessment method more scientific ${ }^{[9]}$, make the evaluation results more objective, and help to improve the performance of safety management.

\section{Construction of Index System of Safety Production Data for Port Enterprises}

\subsection{Classification of Safety Production Data}

The purpose of analyzing the safety production data of enterprises is to grasp the risk state of safety production of enterprises, so as to formulate more targeted and timely control measures to reduce the safety production risk of 
enterprises ${ }^{[10-11]}$. For the actual needs of safety production, in order to grasp the safety production information and analyze the safety production situation, each enterprise should formulate the collection method and frequency of safety production data according to its own actual situation. There is no specific requirement about the collection of safety production data in China's laws, regulations and standards on safety production. However, the relevant laws, regulations and standards about the safety production in China put forward clear requirements on the management work of safety production of enterprises from different angles. For example, according to the Technical Instruction for the Informatization Construction of Safety Production of Enterprises issued by the State Administration of Work Safety in 2016, the information resources of enterprise safety production can be classified from four aspects: safety management, emergency management, occupational health and monitoring. The series of documents of standardized evaluation management about safety production also put forward specific requirements for the collection of some safety production data.

Taking the generation and control of risk factors affecting safety production as the core, the relevant national standards, norms and industry requirements as the basis, and "classification of safety data should be as detailed as possible and reflect the hierarchical relationship" as the principle, this study focused on the generation and control of risk factors affecting safety production, and classified research and analysis on the data of safety production of port enterprises were conducted after the collection of safety production data of several large domestic port enterprises was fully investigated. Finally, the safe production data of port enterprises were divided into ten categories: personnel management, emergency management, equipment and facilities management, construction of safety culture, occupational health management, hidden danger management, risk management, dangerous operation management, related party management, and monitoring management. The classification model diagram of safety production data of port enterprise is constructed, as shown in Fig.1.

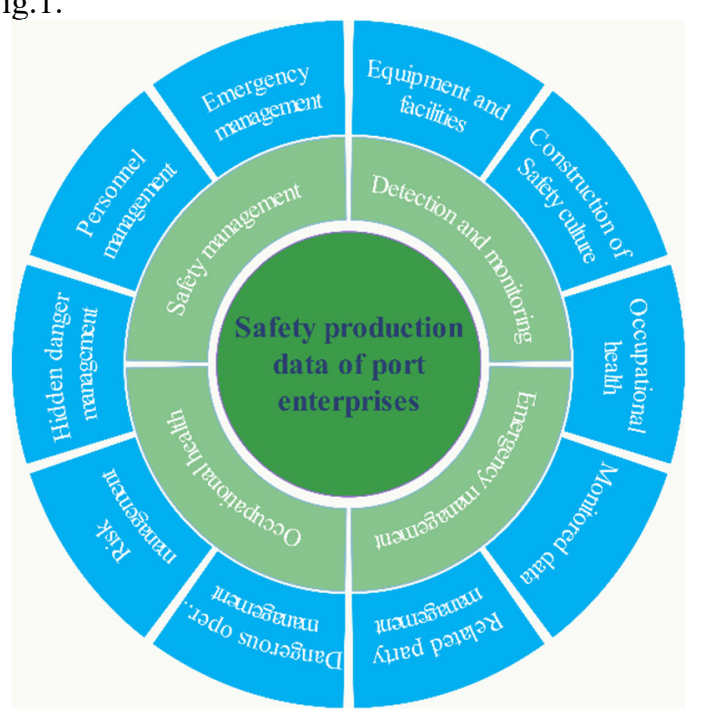

Fig 1. Classification Model Diagram of Safety Production Data of Port Enterprises

\subsection{Hierarchy Structure of Safety Production Data}

In order to balance the convenience of collecting safety data and ensure the effectiveness of the data to represent the safety management situation, by combining the actual management situation of safety production of major port enterprises with the classification model, the ten types of safety production data were subdivided, and finally the detailed data source which can effectively represent the situation of safety production risk of port enterprises was obtained. According to the data source and hierarchical relationship after subdivision, the hierarchical structure table of safety production data was constructed, which included 10 first-level indicators, 52 second-level indicators and 95 third-level indicators. As shown in TABLE I.

Table I. Index system of safety production data

\begin{tabular}{|c|c|c|}
\hline $\begin{array}{l}\text { First-class } \\
\text { indicators } \\
\end{array}$ & $\begin{array}{c}\text { Second-class } \\
\text { indicators }\end{array}$ & Third-level indicator \\
\hline \multirow{20}{*}{$\begin{array}{l}\text { Personnel } \\
\text { management } \\
\text { (B1) }\end{array}$} & \multirow{2}{*}{$\begin{array}{l}\text { The nature of } \\
\text { employment of } \\
\text { personnel (C11) }\end{array}$} & $\begin{array}{c}\text { Number of employed staff } \\
\text { (D111) }\end{array}$ \\
\hline & & $\begin{array}{c}\text { Number of labor } \\
\text { outsourcing personnel } \\
\text { (D112) }\end{array}$ \\
\hline & \multirow{7}{*}{$\begin{array}{l}\text { Education and } \\
\text { training }(\mathrm{C} 12)\end{array}$} & $\begin{array}{l}\text { Training rate for persons in } \\
\text { charge of enterprises } \\
\text { (D121) }\end{array}$ \\
\hline & & $\begin{array}{l}\text { Training rate for full-time } \\
\text { and part-time security } \\
\text { personnel (D122) }\end{array}$ \\
\hline & & $\begin{array}{c}\text { Training rate for special } \\
\text { operators (D123) }\end{array}$ \\
\hline & & $\begin{array}{c}\text { Training rate for special } \\
\text { equipment operators } \\
\text { (D124) }\end{array}$ \\
\hline & & $\begin{array}{l}\text { Training rate for contract } \\
\text { workers }(\mathrm{D} 125)\end{array}$ \\
\hline & & $\begin{array}{l}\text { Training rate of new } \\
\text { recruits (D126) }\end{array}$ \\
\hline & & $\begin{array}{l}\text { Completion rate for the } \\
\text { training courses (D127) }\end{array}$ \\
\hline & \multirow{2}{*}{$\begin{array}{l}\text { Basic quality of } \\
\text { personnel (C13) }\end{array}$} & $\begin{array}{l}\text { Educational background of } \\
\text { personnel (D131) }\end{array}$ \\
\hline & & $\begin{array}{c}\text { Occupational skills of } \\
\text { personnel (D132) }\end{array}$ \\
\hline & \multirow{5}{*}{$\begin{array}{l}\text { Qualification of } \\
\text { personnel (C14) }\end{array}$} & $\begin{array}{l}\text { Certificate holding rate of } \\
\text { persons in charge of } \\
\text { enterprises (D141) }\end{array}$ \\
\hline & & $\begin{array}{l}\text { Certificate holding rate of } \\
\text { full-time and part-time } \\
\text { security personnel } \\
\text { (D142) }\end{array}$ \\
\hline & & $\begin{array}{l}\text { Certificate holding rate of } \\
\text { special equipment operators } \\
\text { (D143) }\end{array}$ \\
\hline & & $\begin{array}{l}\text { Certificate holding rate of } \\
\text { special operators (D144) }\end{array}$ \\
\hline & & $\begin{array}{c}\text { Proportion of certified } \\
\text { safety engineers to safety } \\
\text { personnel (D145) }\end{array}$ \\
\hline & \multirow{4}{*}{$\begin{array}{l}\text { Safety meeting } \\
\text { (C15) }\end{array}$} & $\begin{array}{l}\text { Group-level safety meeting } \\
\text { (D151) }\end{array}$ \\
\hline & & $\begin{array}{l}\text { Corporate-level safety } \\
\text { meeting (D152) }\end{array}$ \\
\hline & & $\begin{array}{c}\text { Department(Team/Station)- } \\
\text { level safety meeting } \\
\text { (D153) }\end{array}$ \\
\hline & & $\begin{array}{l}\text { Shift-level/Group-level } \\
\text { safety meeting (D154) }\end{array}$ \\
\hline
\end{tabular}




\begin{tabular}{|c|c|c|}
\hline $\begin{array}{l}\text { First-class } \\
\text { indicators }\end{array}$ & $\begin{array}{l}\text { Second-class } \\
\text { indicators }\end{array}$ & Third-level indicator \\
\hline & & $\begin{array}{l}\text { Other safety meetings } \\
\text { (D155) }\end{array}$ \\
\hline \multirow{4}{*}{$\begin{array}{l}\text { Key work } \\
\text { management } \\
\text { (B2) }\end{array}$} & \multirow{2}{*}{$\begin{array}{l}\text { Operations on key } \\
\text { processes (C21) }\end{array}$} & $\begin{array}{l}\text { Number of operations on } \\
\text { key processes (D211) }\end{array}$ \\
\hline & & $\begin{array}{l}\text { Number of identified risk } \\
\text { points involved (D212) }\end{array}$ \\
\hline & \multirow{2}{*}{$\begin{array}{l}\text { Hazardous } \\
\text { operation } \\
\text { management } \\
\quad(\mathrm{C} 22)\end{array}$} & $\begin{array}{l}\text { Quantity of hazardous } \\
\text { operations in enterprises } \\
\text { (D221) }\end{array}$ \\
\hline & & $\begin{array}{l}\text { Approval rate of hazardous } \\
\text { work (D222) }\end{array}$ \\
\hline$\ldots$ & $\ldots$ & $\ldots$ \\
\hline
\end{tabular}

\section{Determination of Weight of Evaluating Indicators for Data Security}

As there are many data indicators involved in this study and it is difficult to directly conduct quantitative evaluation, in order to rank individual indicators by their importance, this study uses Analytic Hierarchy Process (AHP) to calculate the weight, which means, the importance of the results is ranked and dispersed to multiple targets, and measured by multiple standards. The indicators at the same level have the same status, and the indicators at the upper and lower level show a dominant relation ${ }^{[8]}$. The steps are as shown below.

\subsection{Establish a hierarchical structure model}

The evaluating indicator system of safety production data consists of goal level, criterion level 1, criterion level 2 and indicator level. The safety production state of a port enterprise covers the goal level (A), and the criterion level includes personnel management $\left(\mathrm{B}_{1}\right)$, Key work management $\left(\mathrm{B}_{2}\right)$, Safety risk management $\left(\mathrm{B}_{3}\right)$, Risk management $\left(\mathrm{B}_{4}\right)$, Related party management $\left(\mathrm{B}_{5}\right)$, Emergency management $\left(\mathrm{B}_{6}\right)$, Occupational health and labor protection management $\left(\mathrm{B}_{7}\right)$, Construction of safety culture $\left(\mathrm{B}_{8}\right)$, Equipment and facilities management $\left(\mathrm{B}_{9}\right)$ and Monitored data $\left(\mathrm{B}_{10}\right)$, and then the corresponding second-level indicators (represented by $\mathrm{C}$ ) and third-level indicators (represented by D) are set, and finally the hierarchy structure model of safety production data is constructed, as shown in Table 1.

\subsection{Constructing a judgment matrix and determining weights}

According to the established hierarchical model, the importance of indicators at different levels is compared by 1-9 scaling method, and the judgment matrix is thus constructed. The judgment matrix is based on relative importance scale. For example, comparing indicator B under indicator $\mathrm{A}, B_{i}$ and $B_{j}$ are compared in importance $b_{i j}=B_{i} / B_{j}$, take any number from 1 to 9 or its reciprocal, which is shown in TABLE II.

Table II. Relative Importance Scale

$$
\begin{gathered}
B_{i} \text { and } B_{j} \text { are compared in } \\
\text { importance } b_{i j}=B_{i} / B_{j}
\end{gathered}
$$

\begin{tabular}{c|l}
\hline Equally important & 1 \\
\hline Weakly important & 3 \\
\hline Essentially important & 5 \\
\hline Strongly important & 7 \\
\hline Absolutely important & 9 \\
\hline
\end{tabular}

After the comparison of all indicators, the judgment matrix $\mathrm{B}=\left[b_{i j}\right]$ of judging $10 \times 10$ is obtained. Then, the normalization operation is carried out, and the single hierarchal arrangement weight is determined. After passing the consistency test, the weight of each indicator is obtained, and the calculation results are synthesized by the sum-product method to obtain the weight value of total hierarchy permutation.

In this study, an expert questionnaire on indicator weight was compiled, and 20 experts from port related industry were invited to give their opinions on indicator weight. The total number of valid return was 18 , and the valid usable return rate was $90 \%$. The weight of each indicator was calculated according to expert opinions, as shown in TABLE III (only part of the results is listed due to the limitation of space).

\begin{tabular}{|c|c|c|c|}
\hline $\begin{array}{l}\text { First-level } \\
\text { indicators }\end{array}$ & $\begin{array}{c}\text { Second- } \\
\text { level } \\
\text { indicators }\end{array}$ & Third-level indicators & $\begin{array}{l}\text { Weight of } \\
\text { third- } \\
\text { level } \\
\text { indicators }\end{array}$ \\
\hline \multirow{18}{*}{$\begin{array}{l}\text { Personnel } \\
\text { manageme } \\
\text { nt } 0.0914\end{array}$} & \multirow{2}{*}{$\begin{array}{c}\text { The nature } \\
\text { of } \\
\text { employme } \\
\text { nt of } \\
\text { personnel } \\
0.0072 \\
\end{array}$} & $\begin{array}{c}\text { Number of employed } \\
\text { staff }\end{array}$ & 0.0036 \\
\hline & & $\begin{array}{l}\text { Number of labor } \\
\text { outsourcing personnel }\end{array}$ & 0.0036 \\
\hline & \multirow{7}{*}{$\begin{array}{l}\text { Education } \\
\text { and } \\
\text { training } \\
0.0131\end{array}$} & $\begin{array}{l}\text { Training rate for persons } \\
\text { in charge of enterprises }\end{array}$ & 0.0019 \\
\hline & & $\begin{array}{l}\text { Training rate for full- } \\
\text { time and part-time } \\
\text { security personnel }\end{array}$ & 0.0019 \\
\hline & & $\begin{array}{c}\text { Training rate for special } \\
\text { operators }\end{array}$ & 0.0019 \\
\hline & & $\begin{array}{c}\text { Training rate for special } \\
\text { equipment operators }\end{array}$ & 0.0019 \\
\hline & & $\begin{array}{l}\text { Training rate for } \\
\text { contract workers }\end{array}$ & 0.0019 \\
\hline & & $\begin{array}{c}\text { Training rate of new } \\
\text { recruits }\end{array}$ & 0.0019 \\
\hline & & $\begin{array}{l}\text { Completion rate for the } \\
\text { training courses }\end{array}$ & 0.0019 \\
\hline & \multirow{2}{*}{$\begin{array}{c}\text { Basic } \\
\text { quality of } \\
\text { personnel } \\
0.0204 \\
\end{array}$} & $\begin{array}{c}\text { Educational background } \\
\text { of personnel }\end{array}$ & 0.0102 \\
\hline & & $\begin{array}{c}\text { Occupational skills of } \\
\text { personnel }\end{array}$ & 0.0102 \\
\hline & \multirow{5}{*}{$\begin{array}{l}\text { Qualificati } \\
\text { on of } \\
\text { personnel } \\
0.0351\end{array}$} & $\begin{array}{l}\text { Certificate holding rate } \\
\text { of persons in charge of } \\
\text { enterprises }\end{array}$ & 0.007 \\
\hline & & $\begin{array}{l}\text { Certificate holding rate } \\
\text { of full-time and part- } \\
\text { time security personnel }\end{array}$ & 0.007 \\
\hline & & $\begin{array}{c}\text { Certificate holding rate } \\
\text { of special equipment } \\
\text { operators }\end{array}$ & 0.007 \\
\hline & & $\begin{array}{c}\text { Certificate holding rate } \\
\text { of special operators }\end{array}$ & 0.007 \\
\hline & & $\begin{array}{c}\text { Proportion of certified } \\
\text { safety engineers to } \\
\text { safety personnel } \\
\end{array}$ & 0.007 \\
\hline & \multirow{2}{*}{$\begin{array}{l}\text { Safety } \\
\text { meeting } \\
0.0156\end{array}$} & $\begin{array}{c}\text { Group-level safety } \\
\text { meeting }\end{array}$ & 0.0031 \\
\hline & & $\begin{array}{c}\text { Corporate-level safety } \\
\text { meeting }\end{array}$ & 0.0031 \\
\hline
\end{tabular}

Table III. Weight sets of indicators at different levels 


\begin{tabular}{c|c|c|c}
\hline $\begin{array}{c}\text { First-level } \\
\text { indicators }\end{array}$ & $\begin{array}{c}\text { Second- } \\
\text { level } \\
\text { indicators }\end{array}$ & Third-level indicators & $\begin{array}{c}\text { Weight of } \\
\text { third- } \\
\text { level } \\
\text { indicators }\end{array}$ \\
\hline \multirow{2}{*}{} & & $\begin{array}{c}\text { Department(Team/ } \\
\text { Station)-level safety } \\
\text { meeting }\end{array}$ & 0.0031 \\
\cline { 3 - 4 } & & $\begin{array}{c}\text { Shift-level/ Group-level } \\
\text { safety meeting }\end{array}$ & 0.0031 \\
\cline { 3 - 4 } & & Other safety meetings & 0.0031 \\
\hline$\ldots$ & $\ldots$ & $\ldots$ & $\ldots$ \\
\hline
\end{tabular}

\section{Fuzzy Comprehensive Evaluation of Safety Production Data}

Fuzzy evaluation method is the comprehensive evaluation of objects affected by multiple indicators by applying fuzzy mathematics principles. Because of its clear results, strong systematicness and easy calculation and operation, it is widely used in evaluation, and is especially suitable for complex cases where the advantages and disadvantages of evaluated objects are not easy to quantitatively evaluate or directly determine ${ }^{[12]}$.

\subsection{Determination of Evaluation Indicator Set}

Among the evaluation indicator set $U=\left\{u_{1}, u_{2}, \ldots, u_{n}\right\}$, $u_{1}, u_{2}, \ldots, u_{n}$ are different evaluation indicators, and $n$ is the number of indicators at the same level. According to the evaluating indicator system of safety production data constructed in this paper, the indicator set $U$ can be divided into three levels of indicator sets. Among them, the evaluation indicator set of first-level indicators: $A=\left\{B_{1}, B_{2}, B_{3}, B_{4}, B_{5}, B_{6}, B_{7}, B_{8}, B_{9}, B_{10}\right\}$.

\subsection{Determination of Evaluation Set V}

In the evaluation set $V=\left\{V_{1}, V_{2}, \ldots, V_{n}\right\}, V_{j}(j=1,2, \ldots m)$ is the evaluation result that may be given, and $m$ is the number of evaluation results that may be given. The set $V$ defines the range of evaluation results.

$V=\left\{V_{1}, V_{2}, V_{3}, V_{4}, V_{5}\right\}=\{$ excellent, good, average, poor, very poor $\}$, which represents eigenvalues of $\{10,8,6,4$, $2\}$ respectively.

\subsection{Determination of weight set}

In the weight set $A=\left\{a_{1}, a_{2}, \ldots, a_{n}\right\}, \quad a_{i}(i=1,2, \ldots, n)$ represents the indicator weight of the indicator set $U$, and $n$ is the number of indicators in $U . a_{i}$ represents the importance of each indicator, and the weight set of this study is calculated by the above analytic hierarchy process.

$$
\sum_{i=1}^{n} \mathrm{a}_{i}=1, \quad 0 \leqslant \mathrm{a}_{i} \leqslant 1(i=1,2, \ldots n)
$$

\subsection{Determination of the membership matrix}

The three levels of indicators of this study are all kinds of safety production data collected from enterprises. According to the size of the safety production data value, the enterprise adopts the expert evaluation method based on the actual conditions. Besides, with five given evaluation grades including excellent, good, average, poor, and very poor, the corresponding evaluation grades are obtained, which is the fuzzy evaluation matrix of the three levels of indicators $R_{c j}$. Taking the evaluation of indicator $u_{i}$ as an example, if its grade of membership of the $j$ element $v_{j}$ is $r_{i j}$, then:

$$
\mathrm{R}\left(u_{i}\right)=\left\{r_{i 1}, r_{i 2}, \ldots, r_{i m}\right\}
$$

$\mathrm{R}\left(u_{i}\right)$ means the evaluation grade set of a single indicator in the indicator system. It is a fuzzy subset of the evaluation grade set $V$. Accordingly, other indicators need single indicator fuzzy evaluation to finally get a fuzzy evaluation grade matrix $R=U \cdot V$.

$$
R=\left[\begin{array}{cccc}
r_{11} & r_{12} & \ldots & r_{1 m} \\
r_{21} & r_{22} & \ldots & r_{2 m} \\
\ldots & \ldots & & \ldots \\
r_{n 1} & r_{n 2} & \ldots & r_{n m}
\end{array}\right]
$$

\subsection{Multi-level fuzzy comprehensive evaluation}

Multi-level fuzzy comprehensive evaluation means multiplying the single indicator membership matrix by the indicator weight set, and obtaining the corresponding calculation results.

$$
\mathrm{B}=\mathrm{A} \cdot R=\left(a_{1}, a_{2}, \ldots, a_{n}\right) \cdot\left[\begin{array}{cccc}
r_{11} & r_{12} & \ldots & r_{1 m} \\
r_{12} & r_{22} & \ldots & r_{2 m} \\
\ldots & \ldots & & \ldots \\
r_{n 1} & r_{n 2} & \ldots & r_{n n}
\end{array}\right]=\left(b_{1}, b_{2}, \ldots, b_{m}\right)
$$

$b_{i}$ is called fuzzy comprehensive evaluation indicator. Perform normalization:

$$
b_{j}^{\prime}=b_{j} / \sum_{j=1}^{m} b_{j}
$$

Obtain standard evaluation results:

$$
B^{\prime}=\left(b_{1}^{\prime}, b_{2}^{\prime}, \ldots, b_{m}{ }^{\prime}\right)
$$

On these grounds, the fuzzy comprehensive evaluation of each level of indicators is carried out to obtain the final fuzzy comprehensive evaluation result $U=\left(a_{1}, a_{2}, \ldots, a_{m}\right)$, which is then normalized to get the final standard evaluation result:

$$
U^{\prime}=\left(a_{1}^{\prime}, a_{2}^{\prime}, \ldots, a_{m}^{\prime}\right)
$$

\section{Verification and Analysis of Evaluation Results}

In this study, 14 monthly reports of safety production data of a large port enterprise were collected, among which accident indicators representing safety management results included working days lost due to accidents and statistics of accident. In this evaluation indicator system, it is not directly used as an evaluation indicator, but as an actual result compared with the evaluation results to revise the evaluation results and improve the evaluation indicator system. Because real-time monitored data of major hazard 
sources are instantaneous, they are not used as evaluation indicators here.

\subsection{Analysis of the Overall Security Status of a Port Enterprise}

The weight coefficient determined by analytic hierarchy process is used to comprehensively evaluate the 14-month safety production data of a port enterprise. The results are shown in Fig. 2 .

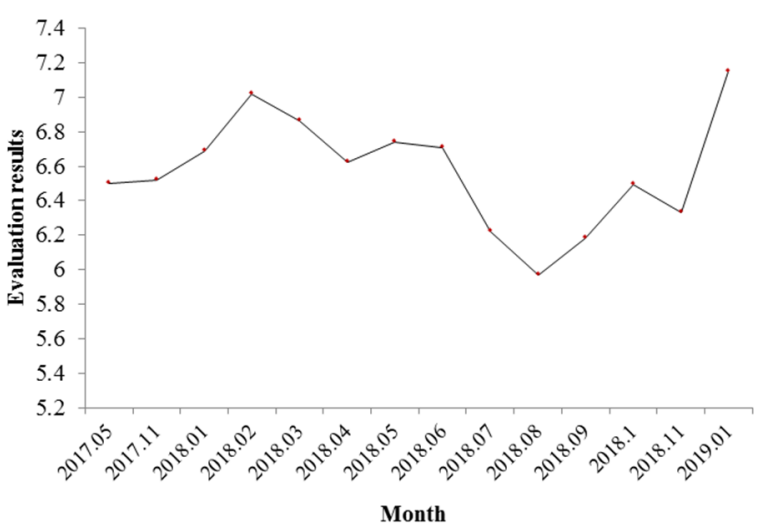

Fig 2. Trend Chart of Evaluation Results of Safety Production Data

It is shown that the evaluation results of 14-month safety production data of the port enterprise are between 6 and 7.5, with an average value of 6.57. In terms of evaluation criterion, it belongs to average or good, generally tending to be average. The months with the poorest evaluation results are August 2018 and September 2018, and the months with the best results are February 2018 and January 2019, which shows that the safety production status is good in winter and poor in summer. In order to facilitate further analysis, the evaluation results of the first-level indicators for 4 months are listed for analysis, and the analysis results are shown in TABLE IV.

Table IV. Evaluation Results of First-level Indicators

\begin{tabular}{c|c|c|c|c}
\hline $\begin{array}{c}\text { First-level } \\
\text { indicators }\end{array}$ & $\begin{array}{c}\text { Results } \\
\text { of } \\
\mathbf{2 0 1 8 . 0 8}\end{array}$ & $\begin{array}{c}\text { Results } \\
\text { of } \\
\mathbf{2 0 1 8 . 0 9}\end{array}$ & $\begin{array}{c}\text { Results } \\
\text { of } \\
\mathbf{2 0 1 8 . 0 2}\end{array}$ & $\begin{array}{c}\text { Results } \\
\text { of } \\
\mathbf{2 0 1 9 . 0 1}\end{array}$ \\
\hline $\begin{array}{c}\text { Related party } \\
\text { management }\end{array}$ & 6.86 & 6.50 & 7.04 & 6.50 \\
\hline $\begin{array}{c}\text { Equipment and } \\
\text { facilities } \\
\text { management }\end{array}$ & 6.64 & 6.64 & 6.64 & 6.64 \\
\hline $\begin{array}{c}\text { Safety culture } \\
\text { management }\end{array}$ & 6.26 & 6.26 & 6.26 & 6.25 \\
\hline $\begin{array}{c}\text { Occupational } \\
\text { health management }\end{array}$ & 7.36 & 6.89 & 6.33 & 6.33 \\
\hline Risk management & 6.68 & 6.10 & 5.01 & 8.09 \\
\hline Risk management & 6.34 & 6.34 & 6.34 & 6.34 \\
\hline $\begin{array}{c}\text { Hazardous } \\
\text { operation } \\
\text { management }\end{array}$ & 3.33 & 4.67 & 10.00 & 8.50 \\
\hline $\begin{array}{c}\text { Personnel } \\
\text { management }\end{array}$ & 7.80 & 7.72 & 7.64 & 7.56 \\
\hline $\begin{array}{c}\text { Emergency } \\
\text { management }\end{array}$ & 5.07 & 6.36 & 6.82 & 6.45 \\
\hline $\begin{array}{c}\text { Monitored data of } \\
\text { safety production }\end{array}$ & 6.00 & 6.00 & 6.00 & 6.00 \\
\hline
\end{tabular}

In summer, the business volume of port production is the largest, and the quantity of hazardous operations, number of identified risk points, number of operations on key processes, etc. will inevitably increase with the rise of business volume, resulting in lower evaluation results of "hazardous operation management" data value with higher indicator weight. In addition, the increase in the number of early warnings such as strong winds and heavy rains in summer also poses great challenges to the production safety. In winter, the business volume of port enterprises is smaller, the safety production business is unsaturated, and the quantity of hazardous operations, the number of identified risk points and the number of operations on key processes are small, resulting in an overall good level of indicators such as "hazardous operation management". Meanwhile, as January and February are approaching the end of the lunar New Year, port management and frontline operators at all levels pay more attention to safety management and raise their safety awareness, resulting in higher comprehensive evaluation results of the three-level indicators, and thus higher safety indicators. The evaluation results basically conform to the actual production of port enterprises.

\subsection{Analysis of Advantages and Disadvantages of Safety Management}

The radar chart of the comprehensive evaluation results of the first-level indicators of a port enterprise for 14 months is shown in Fig.3.



Fig 3. Radar Chart of Comprehensive Evaluation Results of First-level Indicators

As can be seen from Fig.3, the comprehensive evaluation results of the first-level indicators basically remain between 6 and 7 with a little fluctuation, indicating that all aspects involved in the safety management of the port enterprise are equally weighted. Among them, the personnel management stands out, with the evaluation result above 7.5 .

In terms of advantages, the enterprise is relatively complete in aspects such as equipment and facilities management, related party management and personnel management. For example, the data of indicators such as the qualified rate of special equipment inspection, the approval rate of hazardous work, the qualification of personnel, and the education and training of personnel are basically maintained between $98 \%$ and $100 \%$, reflecting that the enterprise has made much investment in related management work and implemented all the work well. 
In terms of disadvantages, the port enterprise still needs to strengthen efforts in occupational health management and risk management. For example, physical examination of personnel, and education and training on occupational hazard, need to be strengthened. The pass rate of testing point in occupational hazard and the participation in reporting hidden dangers need to be improved, and especially the awareness of front-line personnel to actively discover and report hidden dangers needs to be improved. The overall number of comprehensive inspections, special inspections and inspections in special periods is relatively small, and the rectification rate of hidden troubles needs to be improved, which affects the overall evaluation score of risk management.

\subsection{Measures and Suggestions for Improvement}

According to the evaluation indicator system of safety production data proposed in this study, it can be seen from the weight of each indicator that weights of hidden danger management, risk management, and dangerous operation management are the highest. Thus, controlling the risks of these three indicators will help reduce the overall risk level of the enterprise and improve the overall safety production state.

In terms of hidden danger management, indicators such as the number of hidden dangers, employees' participation in reporting hidden dangers, and the rectification rate of hidden dangers greatly impact the safety production state. Thus, the safety production state can be improved by reducing the number of hidden dangers, increasing the timely rectification rate of hidden dangers, and improving employees' active participation in reporting hidden dangers.

In terms of risk management, from the perspective of risk control, we can strengthen the implementation of prevention and control measures for existing hazard sources, reduce risk levels, and improve the awareness of risk prevention and control of staff at different levels.

In terms of dangerous operation management, the safety production state is directly related to the size of business volume. The increase of business volume and the quantity of hazardous operations will inevitably raise the safety risks of production operations. To improve the safety production state, we can start from the perspective of the construction of safety culture, the upgrading of enterprises meeting the standards of safety standardization, and the construction of "dual preventive mechanism" for risk classification prevention and control and hidden danger identification and governance, etc., and strengthen the working mechanism of standardization of key processes and hazardous operation control processes, thus further consolidating the existing safety management model.

At present, the safety production data of the port enterprise is manually submitted and counted, which not only consumes a lot of manpower but also is errors-prone, counting against the timeliness and accuracy of safety state assessment. It is suggested that an information platform for safety production data collection can be established in the later period or a safety production data submission module can be established based on the existing information system, and the safety state assessment model constructed in this study can be embedded. The statistics and analysis of safety production data can be implemented by means of information technology to improve the efficiency of safety management.

\section{Conclusions}

Based on the requirements of relevant laws and regulations, and using methods such as analogy, investigation and survey, this paper has defined the data resources collected by port enterprises and which can effectively describe the safety management, constructed a three-level safety production data indicator system of port enterprises, determined the weight of each indicator through the analytic hierarchy process, and established the analysis and evaluation method of "AHP-fuzzy comprehensive evaluation" of port enterprises' safety production data. By collecting, classifying and sorting out the safety production data sources of port enterprises, the verification and analysis of the evaluation model are carried out, and the evaluation results basically conformed to the actual conditions of safety production of port enterprises. This safety production data evaluation model is of great practical significance for making full use of enterprises' safety production data, digging deep into the weak points of enterprises' safety production and accordingly improving the safety production state.

\section{Acknowledgment}

The author(s) disclosed receipt of the following financial support for the research, authorship, and/or publication of this article. This research is supported by the special fund for the basic research business of the central public welfare research institutes (TKS190108; TKS190114).

\section{References}

1. P. Deng, S. Lu , H. Xiao, Evaluation of the relevance measure between ports and regional economy using structural equation modeling[J]. Transport Policy, 2013, 27(may),pp. 123-133.

2. C.Y. Che, J.G. Liu, J. Li, Entropy weight-TOPSIS based port safety assessment [J]. Journal of Dalian Maritime University: Natural Science Edition, 2016.

3. C.Huang, Y. Bai, S.F. Zhan, Evaluation model of safety performance of general cargo port enterprises based on fuzzy theory [J]. Journal of Waterway and Harbor, 2019, 40(02),pp. 117-122.

4. S.F. Zhan, Ministry of Transport. Guidelines for the Standardization Construction of Safety Production for Port General Cargo Terminal Enterprises [M]. China Communications Press, 2012.

5. Z. Yang,A.K.Y. Ng , J. Wang, A new risk quantification approach in port facility security 
assessment[J]. Transportation Research Part A, 2014, 59(jan.),pp. 72-90.

6. Y. Li, W. Wang, B.X. Liu, et al, Research on Oil Spill Risk of Port Tank Zone Based on Fuzzy Comprehensive Evaluation[J]. Aquatic Procedia, 2015, 3,pp. 216-223.

7. X. Lu, W.G. Liu, Study on the DHGF model applied in Port Loading \& Discharging Safety Management Assessment [J]. Storace Transportation \& Preservation Of Commodities, 2008.

8. Y.J. Cao, Reseach on enterprise safety production early warning system based on big date [D],pp.10-13.

9. F. Wang,J. Lin,Y. Li,X. Yang, Research on Risk Assessment Method of Power Industry Field Operation Based on Big Data [J]. Value Engineering, 2018, 37(33) ,pp. 9-12.

10. C. Xu, Research of Risk Assessment and Warning Index of Cruise Port [D] ,pp.10-15.

11. L.Q. Tao, Study on Corporate Safety Performance Indicator System [D]. Capital University of Economics, 2009,pp.24-30.

12. J.Q. Shen, Study on evaluation index system of the government Production safety accidents emergency management capability [D] ,pp.31-39 